\title{
Family recreational environment and its relation with some values for secondary school students in Dakahlia governorate
}

*Ass.Prof/ Mohamed El Sayed El SayedMatar *** Ass.Prof/ Hazem Mohammed Yousef Mansour Research Summary

The researchers conducted this study to identify the relationship between family recreational environment and some values for secondary school students in Dakahlia Governorate. The researchers used descriptive approach, and applied family recreational environment scale and some values scale as data collection tools. The study was applied to a sample of (1131) from secondary school students in Dakahlia governoratefor the basic sample and (50)students for the survey sample.

The most important results were: parents are aware with

recreationstatuswithinfamilyco ntext; there is a correlation betweenfamily recreational environmentand some moral and social values for secondary school students. The most important Recommendations were The country has to pay attention to families' awareness and developan information strategy based onmoral and social values, and the need to activate it in accordance with this age spiritwithin an educational philosophythat achieves society's goals.

Introduction and research problem

Recreation is one of the most important ingredients in educational process, which helps in educating young people in a comprehensive and integrated way in all stages of growth. It also represents the progressive aspect of contemporary education process because it pays great attention to life and practical aspects of various stages of growth (Shehata:2004).

Family is the first group environment in which child lives in, where it represent the first social cell that places its

*Assistant professor at Sports Recreation Department, Physical Education Faculty, Mansoura University.

${ }_{* *}^{*}$ Assistant professor at Sports Recreation Department, Physical Education Faculty, Mansoura University. 
mark on children's future, that affects person'sgrowth and learns how to deal with others around him. Family is also an important recreational environment that has an affective and big role in helping children to achieve a comprehensive and balanced growth and achieve social cohesion through sound recreational and social upbringing process that have a significant impact on their personal features individually and collectively as well as directing and controlling their behaviors to become citizens who corresponds appropriately with society nature and prevailing values.

Values are important in society, where social structure integration depends on similarity in value system among itssociety members; the greater the similarity between them, the unity of society has become more cohesive, while disparity and difference of these value systems among them lead to difference in values and conflict between society members, which in turn leads to society disintegration and collapse (Shadia:2003).
Lately, Egyptian society suffered from some rapid changes in values and social behaviors as a result of cultural changes, in which internet misuse is its most important tools, beside emergence of some satellite channels that show many bad media content below value level, also viewers' passion and desire to watch and follow programs led to fall in some spiritual and social values and therefore disorder in moral system and social values, that made us describe current period as a real crisis in values and caused imbalance in holding ethics.

As values are formed within various society institutions, including family, and because individuals' behavior is largely influenced by surrounding environment, we found that student within his family environment is influenced by parents' tendencies and hobbies. Therefore, family recreational environment encourage its children to recreational practice and create participation opportunities in various recreational fields, which help to instill and establish moral and social values in children 
souls, and thus prepare people who behave in a socially acceptable manner consistent with society values, and becomecitizens able to improvetheir country. As secondary school students occupy a great positionwithinsociety, they are who make future men. So, preparing them in a good way contributestosocietybuilding, prosperityand progress, and this led researchers to study family recreational environment and its relation to some values forsecondary school students in Dakahlia governorate.

Research Importance and Need:

Importance of research is highlighted in the following points:

1. Drawing attention of parents and educator storecreational participation importance with in family and its positive effects in modifying behaviors and attitudes of children and changing it for the better.

2. This research benefits those interested researchers at recreational activitiesat educational and educational institutionsinforming positive attitudes for students towards recreational practice, which develop and promote moral and social values and remove negative values.

3. This research will contributeto enrichingfield of Arab studies and researchesinsocial and educational sciences,especially in relation to leisure time and recreation,to assist researchersin conducting studies on this subject and linking them to other variables.

Study Purpose:

This research aims to identifythe relationship betweenfamily recreational environmentand some values for secondary school students in Dakahlia governorateby answering the following questions:

1. Whatisrecreationstatus and objectivesinfamily for secondary school students?

2. What are recreational activities and challenges that face recreationpracticein family for secondary school students?

3. What are moral and social valuesof secondary school students?

4. What is the correlation betweenfamily recreational 
environmentand some values for secondary school students in Dakahlia governorate?

5. Are there any statistically significant differencesinfamily recreational environment and some values for secondary school studentsdue to (gender, practice places, practice hours)?

Study procedures

The

researchers

useddescriptive approachwith survey methoddue to its relevance toresearchnature.

Research Community and Sample:

Research community consists of secondary school students in Dakahlia governorate.The researchers randomly selectedthe sample, which consisted (1131) of secondary school students in Dakahlia governorate for basic sample and (50) for exploratory sampleoutside the basic sample.

\section{Data collection tool:}

Scale of the recreational environment consistsof (55) phrases distributed over (4) dimensions, andscale of some values for secondary school students consists of (72) phrases distributed on (2) dimensions, prepared by the researchers.

Steps to design family recreational environment scale and some values scale for secondary school students in Dakahlia Governorate:

Through theoretical readings and reference studies and surveying views of (7) experts in recreation and psychology (Appendix A), researchers prepared a scale offamily recreational environment and a scale of some values for secondary school students. The family recreational environment scale contains (4) dimensions: Recreation status withinfamily context- Objectives of family recreational activities- Family recreation activities- Challenges to recreation practice within family. The scale of some values contains (2) dimensions :moral values (including responsibility, motivation for achievement, honesty)and social values (including belonging and citizenship, social participation, freedom of opinion and expression).

The preliminary version of the two proposed scaleswas presented toexperts, they 
agreed

on

dimensionsforrecreational

environment scale (Appendix

B)and (2) dimensions forsome valuesscale (Appendix C).

In light of experts' agreementondimensions

offamily recreational environment scaleconsisting of (69) phrases, after excluding phrasesinfirst dimension, and (1) phrase insecond dimension, (2) phrases in third dimension, (3) phrasesinfourth dimension, because these phrases didn't gain (75\%) ofexperts' agreement, and thus the scale consisted (61) phrases. Researchers conducted internal consistencyvalidity, and deleted (6) phrases from the scale: (1) phrase infirst dimension, (2)in second dimension, (2) in third dimension, (1) in fourth dimension. So, scale phrases became (55) phrases distributed on (4) dimensions in its final version:Recreation status withinfamily context (13 phrases) -Objectives of family recreational activities (15 phrases)- Family recreation activities (15 phrases)Challenges to recreation practice within family (12 phrases) (Appendix D).
In light of experts' agreementondimensions

ofsome valuesscaleconsisting of (90)phrases,after excluding (6) phrasesinfirst dimension, and (5) phrase insecond dimension, because these phrases didn't gain (75\%) ofexperts' agreement, thus scale became

phrases.Researchers conducted internal consistencyvalidity, and deleted (7) phrases from the scale:(4) phrasesinfirst dimension, and(3) phrases insecond dimension. And thus, scale phrases became (72) distributed on (2) dimensions in its final version;moral values includes: responsibility (12 phrases)- motivation for achievement (12 phrases)honesty (11 phrases), and social values includes: belonging and citizenship (12 phrases)- social participation (13 phrases)freedom of opinion and expression (12 phrases) (Appendix H).

The degree of each dimension is determined, besides determining total scoreby a triangular balance (yes $=3$ degrees - to some extent $=2$ degrees - no $=1$ degree), thencalculating total score ofthe scale. 
Field study:

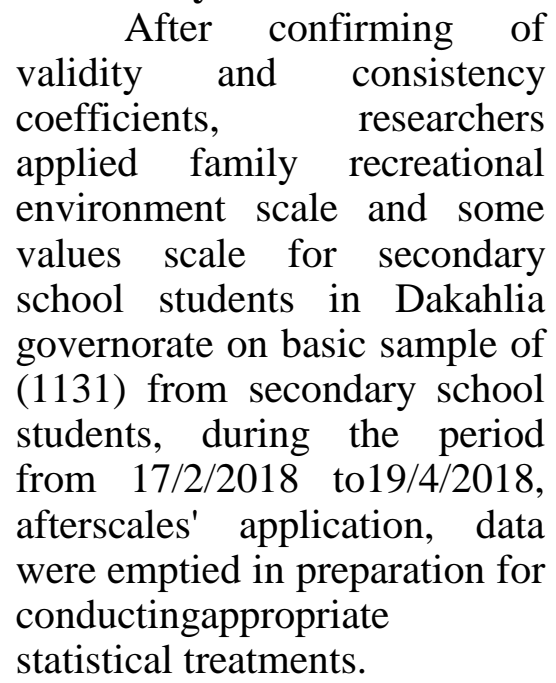

Results presentation and discussion:

1. Frequency and percentages of recreation status within family context for secondary school students.

Table

showsstudents'awareness

of recreation status withinfamily context, where the highest phrase was "your family members believe that leisure time investment increases its value" with (84.232\%), and this may be due toparents' realizationthe importanceo fpracticing recreational activitiesin leisure time and their positive impact on family life. This is consistent with (Hany,2010) that there is awareness ofrecreational basic conceptsand

recreational activities in families.

\section{Frequency and percentages of family recreational activities' objectives for secondary school students.}

$$
\text { Table (10) shows }
$$

students' awareness of family recreational activities' objectives, where the highest phrase was "leisure time investment for family members"with (85.794\%), and this may be due toparents'awarenessof leisure time importanceandneed to exploit it in useful activitiesto get rid ofschoolburdens, this is consistent with(Haider, 2017)that parents are keen to help their family members to invest Leisure time by providing recreational activities.

3. Frequency and percentages of family recreational activities for secondary school students.

Table (11) shows that one of family recreational activities "entertainment and watching television and radio programs" came in first position with $(86.531 \%)$, this may be due totelevision and radio are one of the main recreational meansinhome for all families.This is consistent 
with(Metwally,2006) that social and cultural recreational activities are among the most important recreational family interests.

\section{Frequency and percentages of challenges to recreation practice within family for secondary school students.}

Table (12) showsarrangement of challengesto recreation practice within family, where the highest phrase was "parents' reluctance to participate and superviseof recreational activities" with $(82,847 \%)$, this may be due tosome parents' busyness oftheir role in raising their children as a result oflife pressures, this is consistent with(El-Samanoudiet al,2015) that the most important challenges of recreational activities are time constraints and preoccupation with other burdens.

\section{Frequency and} percentages of moral values (responsibility) for secondary school students.

Table (13) shows that the highest phrase in "responsibility" was "make sure tobe a model and a good example of my colleagues in all my actions" with (93.133\%), due toimportance offamily environment and its role indevelopment and stabilization and strengtheningchildrenvalues, this is consistent with (Hamdino, Khamis, 2016) that students' participation in recreational activities encourages them to have good morals and bear responsibility.

6. Frequency and percentages of moral values (motivation of achievement) for secondary school students.

Tables (14) show that the highest phrase in "motivation of achievement" was "I seek to achieve a high degree of success" with (96.833\%), this is due tomany students in this ageareinterested in and aspire to achieve a prestigious social position, this is consistent with(Hue ,2018) that students' participation in services and recreational activities contribute to raising level of motivation for achievement.

7. Frequency and percentages of moral values (honesty) for secondary school students.

Table (15) show that the highest phrase in "honesty" was "I commit to honesty in 
allmy words and actions" with (81.333\%), due toparents' interestin sound social upbringing of their children,this is consistent with (Kassim, 2017) that honesty is one of the most important moral valuesacquired by students through participation in activities.

8. Frequency

and percentages of social values (belonging and citizenship) for secondary school students.

Table (16)show that the highest phrase in "belonging and citizenship" was "I respect and appreciate the national anthem" with (88.167\%), this is due tofamily environment interest in providing recreational atmosphereand encouraging participation in some social activitiesthat serve community, this is consistent with(Hamdino,Khamis,2016) ,thatstudents' participationin activitiesto develop pride and belonging to country and maintain it.

9. Frequency and percentages of social values (social participation) for secondary school students.

Table (17)show that the highest phrase in"social participation" was "I share my family in some household burdens" with $(87.767 \%)$, this is due toparents' interest in raising their children and encouragingthem to participate and cooperate between family members, either inside or outside home, this is consistent with (Hue ,2018) that students' social participation has a positive impact on social values.

10. Frequency and percentages of social values (freedom of opinion and expression) for secondary school students.

Table (18) show that the highest phrase in "freedom of opinion and expression" was "I feel that society gives me the freedom to express my views on raised issues" with (84.467\%), due to technological progress and multiplicity of modern methods and techniques related to information and communication, this is consistent with (Kassim,2017) about students' awarenessof some social values in modern upbringing, including freedom of opinion and expression and their desire to practice. 


\section{Table (1)}

\section{Correlation coefficients between dimensions of family recreation} environment and some values for secondary school students.

\begin{tabular}{|c|c|c|c|c|c|c|c|c|}
\hline \multirow{3}{*}{\multicolumn{2}{|c|}{ Variables }} & \multicolumn{6}{|c|}{ Scale of some values for secondary school students } & \multirow{3}{*}{$\begin{array}{l}\text { Scale } \\
\text { Total } \\
\text { degree }\end{array}$} \\
\hline & & \multicolumn{3}{|c|}{ Moral values } & \multicolumn{3}{|c|}{ social values } & \\
\hline & & Respo & Motivation & & Belonging & Social & $\begin{array}{l}\text { Freedom } \\
\text { of opinion }\end{array}$ & \\
\hline \multirow{5}{*}{$\begin{array}{l}\text { scale of } \\
\text { Family } \\
\text { recreation } \\
\text { environment } \\
\text { for } \\
\text { secondary } \\
\text { school } \\
\text { students }\end{array}$} & $\begin{array}{l}\text { Recreation } \\
\text { status } \\
\text { within } \\
\text { family } \\
\text { context }\end{array}$ & 388. * & 374. * & 398. * & 434. * & 432. * & 415. * & $542 . *$ \\
\hline & $\begin{array}{l}\text { Objectives } \\
\text { of family } \\
\text { recreational } \\
\text { activities }\end{array}$ & 449. * & 457. * & 400. * & 468. * & 487. * & 476. * & $615 *$ \\
\hline & $\begin{array}{l}\text { Family } \\
\text { recreation } \\
\text { activities }\end{array}$ & 406. * & 390. * & 371. * & 445.* & 411. * & 423. * & $546 . *$ \\
\hline & $\begin{array}{l}\text { challenges } \\
\text { to } \\
\text { recreation } \\
\text { practice } \\
\text { within } \\
\text { family }\end{array}$ & 434. * & 393. * & 360. * & 433. * & 382.* & 404. * & $540 . *$ \\
\hline & $\begin{array}{l}\text { Scale total } \\
\text { degree }\end{array}$ & 544. * & 524. * & 496. * & $579 . *$ & $556 . *$ & $559 . *$ & 728. * \\
\hline
\end{tabular}

Value of " $\mathrm{t}$ " table at a significant level of $0.05=0.062$
Table
(1) shows a
providing a
recreational

statistically significant correlation environment.

between dimensions of family recreational environment and some values for secondary school students, all valuesare significant at 0.05 level. This may be due to encouraging role ofrecreational environment in investing leisure time inside family context,this is consistent with(Haider,2017) that parents help their family members to invest leisure time by

\section{Significance of} differences in family recreational environment for secondary school students, which is attributed to gender (male - female)

Table (20) shows that there are no statistically significant differences between"family recreational environment" dimensionfor secondary school students according togender variable, 
where calculated value $(\mathrm{t})$ is less thantabular value at a significant level (0.05), this may be due to parents' concern in providing participation opportunities in various recreational activities for their children without discrimination between males or females, this is consistent with(Haider, 2017) in the absence of statistical differences betweenstudents according togender variable ininterests and recreational participation.

12. Significance differences in family recreational environment for secondary school students, which are attributed to practice places (inside home outside home)

Table (21) shows thatthere are statistically significant differences between"family recreational environment"

dimensionaccording tovariable of practice placesfor the benefit ofoutside home, wherevalue of (t) calculated is greater than its tabular valueat a significant level (0.05), this may be due tothat students at this age need to satisfy manyof their various wishes and recreational needsprovided by recreational institutions (clubs, youth centers, cultural palaces, museums, and parks). This is consistent with(Sayed ,2009)about interest in participatingin some recreational programs and activities provided outside the family.

13. Significance of differences in family recreational environment for secondary school students, which are attributed to practice hours (less than one hour - more than an hour) Table (22) shows that there are statistically significant differences between"family recreational environment"

dimensionaccording tovariable ofpracticehoursin favor of more than one hour, where value of $(t)$ calculated is greater thantabular value at a significant level (0.05), this may be due tothat most studentsneedto practice various recreational activitiesto take advantage of leisure time,especially in increasingmodern technology.

Research Conclusions:

- Parents are aware with recreationstatus with in family contextand the importance 
ofproviding a recreational environmentthat gives students the opportunity to invest their leisure time as an important part oftheir total time.

- There is a correlation betweenfamily recreational environmentand some moral and social values for secondary school students.

- $\quad$ There are statistically significant differences invalues dimensionfor secondary school students according tovariable of practice hoursin favor of more than one hour.

\section{Research Recommendations:}

- The country has to pay attention to families' awareness and developan information strategy based onmoral and social values, and the need to activate it in accordance with this age spiritwithin an educational philosophythat achieves society's goals.

- The country has tosupportthe establishment of integrated recreation centers that servefamilies in all governorates.

- Working to

activatecommunity participationbetween recreational institutions and educational institutionsto provide recreationalcare for students to invest their leisure time.

\section{References:}

1- Haidar Ali (2017): Family role in recreational culture of children in age group of 12 to 15 years at DhiQar Iraq, unpublished Master thesis, Physical Education Faculty for Girls, Alexandria University.

\section{2- Hamdino Omar,Mohamed} Khamis (2016): Role of recreational activities in developing students' values in preparatory school from physical education teachers' views, published research, Journal of Physical Education Faculty, Mansoura University, $28^{\text {th }}$ edition.

3- Hany Ali (2010): Effect of some social controls on practicing recreational activities at the stage $15-18$ years in Fayoum Governorate, comparative study, unpublished $\mathrm{PhD}$ thesis, Physical Education Faculty for Girls, Alexandria University.

4- Hue, M (2018): Religious Engagement and Attitudes to the Role of Religion in society: Their Effect on civic and social values in an Asian, British Journal of Religious Education, v. $40 \mathrm{n} 2, \mathrm{p} 158-168$. 
5- Hassan Shehata (2004): School Activity - Concept, Functions and Fields of Application, 8th Edition, The Egyptian Lebanese Library, Cairo,p.p 23.

6- Mohamed Elsamanoudy et al (2015): relationship of participation in recreation camps with social responsibility of university students, published research, Journal of Physical Education Faculty, Mansoura University, $28^{\text {th }}$.

7- Mohsen Kassim (2017): Some Values Ruling Educational Practices in Secondary school and its Role in developing Students' Awareness of their national responsibilities. A Field Study in Dakahlia Governorate, unpublished $\mathrm{PhD}$ Thesis,
Faculty of Education, Mansoura University.

\section{8- Mohamed Metwally}

(2006): family role in forming cultural recreational awareness about investing leisure time, unpublished master thesis, Physical Education Faculty, Tanta University.

9- Mohamed Sayed (2009):

Common recreational concerns and their impact on family cohesion, unpublished master thesis, Physical Education Faculty, Helwan University.

\section{0- Shadia Al-Tal (2003):}

Value System for Zarqa University Students, published research, Mu'tah Magazine for Research and Studies, Series of Human and Social Sciences, $1^{\text {st }}$ edition, p.p15. 